\title{
S sciendo
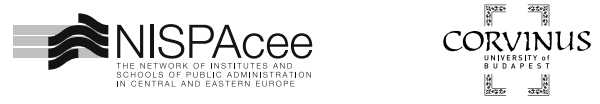

\section{The Hungarian Experiences with Handling Irregularities in the Use of EU Funds}

\author{
Györgyi Nyikos ${ }^{1}$, Zsuzsanna Kondor ${ }^{2}$
}

\begin{abstract}
Using European Union funds involves a complex process; Member States must adhere to wide-ranging EU and domestic legislation, non-compliance can lead to irregularities. Besides accordance with the letter of the law, also the general EU budgetary principles, in particular sound financial management, must be given full consideration. The paper presents Hungary's evolving approach to handling irregularities and her experience in creating the corresponding legal and institutional framework. The research also assesses how the perspective of the European Commission, in particular of its auditors, has contributed to legal uncertainties.

In the draft legislation for the 2021-2027 budgetary period, the European Commission proposes a new requirement, namely the rule of law conditionality. ${ }^{3}$ Its clarity and objectivity, however, are still being widely discussed. Additionally, cohesion policy conditionalities have always contained an obligation for the proper functioning of the institutions - including the courts. Nonetheless, the European Commission has not previously examined the performance of the courts in relation to proceeding irregularity and recovery disputes. The presented Hungarian case study not only explains the particular challenges that call for revisiting the appeal system in Hungary; it warns of the general difficulties Member States may face when embedding the irregularity and recovery management functions into their national legislation, whereas the paper also gives notice to the long-awaited analysis of the root problems invoking irregularities.
\end{abstract}

Keywords:

EU Funds, irregularities, Cohesion Policy

1 National University of Public Service, Budapest, Hungary.

2 National University of Public Service, Budapest, Hungary.

3 COM (2018)324 final, Rule of law conditionality proposal. 


\section{Introduction}

In the period 2014-2020 Hungary receives over Euro 25 billion from the European Structural and Investments Funds (ESIF), the legal and regular implementation of these funds bears critical importance. A key element is the ability to absorb EU funds for cohesion, which is defined as "the capability of a region or member state to allocate and to fully spend the financial resources under cohesion policy in an efficient and effective way" (Dragan 2008; Horvat 2005); it measures the extent to which a state/region is able to fully spend the allocated financial resources from the EU funds in an effective and efficient way (Kopeva et al. 2011). Governments deployed efforts to prevent and manage the deficiency of absorption capacity (Horvat and Maier 2004) and absorption bottlenecks (Kalman 2002).

Whereas there is a most extensive literature evaluating the implementation of Cohesion Policy, in comparison with its significance, the functionality and key ingredients of its compliance enforcement regime have enjoyed examination at a somewhat lower intensity. Studies articulate the correlation between simplification, compliance and performance (Davies 2015; Mike and Balás 2015), the importance of legal certainty in the financial control and audit of the funds (Meuleman and Brenninkmeije 2017), the role of the accountability framework (Koedijk 2016) and the weight of administrative and institutional capacity (among others Šumpíková et al. 2005, Mendez and Bachtler 2017).

Unauthorised and irregular use of assistance in a project may undermine reaching its goals, moreover - at a programme level - it may divert aid from other important investments (Jurevičienė and Pileckaitè 2013). Detecting, investigating and sanctioning non-compliance tie up the delivery institutions greatly, and pending irregularities deepen programme-level financial management risks. The importance of an adequate irregularity regime cannot be overstated. Global challenges, increasing political pressure, media ${ }^{4}$ and public attention have led to the continued tightening of general and irregularity-specific norms, compounded by a complete recalibration of the institutional set-up with each programming period in Hungary (Nyikos 2012), doubtless to be revisited for the post-2020 era.

Since the early 2000s, there has been a huge growth in the complexity of regulations, related directly or indirectly (e.g. horizontal policies) to Cohesion Policy implementation. ${ }^{5}$ This course has been driven significantly by the intention to improve financial management and control of the funds (Davies and Polverari 2011) and characterised the blurring of hard law and soft law, as evidenced in the broader EU governance context, too (Grazianoa and Halpern 2015). Beneficiaries' inability to capture and cope with the patchwork of rules spur frustration and resistance

4 For the impact of media on the theme of irregularity see Triga et al. (YEAR).

5 Final conclusions and recommendations of the High Level Group on Simplification for post 2020, https://ec.europa.eu/regional_policy/sources/newsroom/pdf/simplification_proposals.pdf. 
(Jouen 2008) and erode legality, as none of the conditions the OECD defined as a minimum factor to compliance (sufficient degree of knowledge of, willingness and ability to comply with the rules by the target groups; Parker 2000) materialised. European Commission audits have played a critical role in the rising rigidity (Nyikos 2011); the legal development of corresponding financial corrections reflect the aim of protecting compliance through deterrence (Eacny 2017). A study warned that uncorroborated audit findings, when enforced through the ultimate power of financial sanctions, propel risk-evasiness, the introduction of further constraints thus reinforcing the viscious circle (AAM Consulting 2012). Pressure has also proven harmful in terms of encouraging more focus on procedures rather than on the underlying content (Wostner 2007). Irregularities occur using EU funds in public procurement and problems linked with cronyism, which are the key vulnerable areas where the corruption occurs (Suwaj 2005).

European legislation provides for the protection of the Union's financial interests in all aspects. An error is any breach of rules, an unintentional mistake which does not mean that funds have been lost, wasted or abused. The term is not covered by the antifraud norms. ${ }^{6}$ Irregularity means any infringement of a provision of European law which has, or would have, the effect of prejudicing the general budget of the European Union or budgets managed by it. Non-compliant spending leads to a less efficient and/or effective use of public funds and it could cause damage to the budget. It is notable that breaches of both EU law and national law are relevant, and it is enough if there is a potential prejudice to the EU's budget, it is not necessary to prove that an actual loss to the budget in fact occurred. A fraud implies intentional deception (Nyikos and Tátrai 2012), it affects the European Communities' financial interests and consists of ${ }^{7}$, in respect of expenditure, any intentional act or omission relating to:

- the use or presentation of false, incorrect or incomplete statements or documents which leads to the misappropriation or wrongful retention of EU budget;

- non-disclosure of information in violation of a specific obligation, with the same effect;

- the misapplication of funds for purposes other than those originally approved.

The concept of irregularity is much wider than that of fraud. The latter constitutes a criminal act which is established by judicial proceedings. Therefore, the

6 For the employment of the term "error", see the European Court of Auditors' Annual Report of the European Court of Auditors on the implementation of the budget concerning the financial year 2009, OJ C 303/02, 9.11.2010. Because of the different methods to collect the data, the European Court of Auditors and the Commission agree that the figures of the European Court of Auditors on errors and of the Commission on irregularities and financial corrections cannot be compared in a meaningful way (OJ C 303/02, 9.11.2010, point 1.50, 32, 33). On the methodology of the Court, see Annex 1.1 (Audit Approach and Methodology) OJ C 303/02, 9.11.2010, 34.

7 Article 1(1), point (a), of the "Convention on the Protection of the European Communities' Financial Interests" (PIF Convention). 
financial damage of fraudulent practices can only be determined once the judicial procedure has come to an end. The legal definition and interpretation of irregularities have affected the volume of cases, risks and the corresponding institutional setting. The construction of its meaning reflects both that i.) provisions in the EU legislation have evolved over time and ii.) national governments may have expanded the definition in the national legislation.

In the period 2004-2006 the Community law solely ruled on the EU budget interest. Also the interpretation of loss to the EU budget needed clarification. The concept of actual loss enjoyed a widely shared understanding; it referred to an irregularity which has only been detected after the reimbursement of the underlying expenditure was reimbursed from the budget. Consequently, the budget bore expenses that it should not have paid for, due to their irregular nature. However, defining a potential loss to the budget created many difficulties. This notion assumed that the breach of the rules could have theoretically affected expenditure paid by the budget. The interpretation of the term largely impacted the recording, investigating, reporting, correcting and recovering of irregularities. Neither the EU nor the Hungarian legislation defined the earliest starting point of a potential irregularity. Interpretation varied, some intermediate bodies took the date of the submission of the project proposal. This approach lengthened the process for a formal rejection of the application. Substantial differences prevailed in statistical data originating from Member States which held that an irregularity only relates to reimbursed expenditure and must be confirmed by relevant administrative/judicial proceedings and from countries that employed a much broader interpretation of an irregularity and also accomplished their investigations in a relatively short period of time under administrative proceedings.

Furthermore, as an additional complication, the practice set up for the European Rural Development Funds in Hungary greatly diverged from the mechanisms under the Structural and Cohesion Funds: an irregularity implied a formal administrative decision giving effect to the right to recover undue public assistance. Differences across the funds became tangible. In a 2006 audit report ${ }^{8}$ Hungary, among various other Member States", was suggested to address the "lack of clarity as to what constitutes an irregularity". Additionally, the report warned of the need to distinguish between breaches of the norms with evidenced public financial loss and violations with no impact on the budget.

82006 Report to the Contact Committee of the Heads of the Supreme Audit Institutions of the EU Member States and the European Court of Auditors.

9 CZ, D, E, I, LT, NL, PL, UK. 
A special case is an irregularity related to financial instruments $(\mathrm{FI})^{10}$; the latter support economically viable investments through loans, guarantees, equity and other risk-bearing mechanisms (Nyikos and Soós 2018). The possibility to re-invest the revolving funds offers greater flexibility. The fund manager can remove irregular items before the payment claim is sent to the European Commission. The uncharged expense is recovered by the beneficiary, nonetheless irregularity does not trigger loss at the closure of the instrument. Blending two types of financial support (grants and FIs) implies that an irregularity in one component may affect progress in the other.

The research on the evolution of Hungary's irregularity system is based on the relevant past and present legislation, literatures, evaluations and the experiences of the authors in order to collect and assess the relevant factors which may influence the results the use of EU Cohesion Policy funds bring about. The regulatory and institutional environment strongly affects the likelihood of irregularities; national and EU control and audit reports, irregularity documentation reflect the actual occurrence, nature and impact of non-compliance cases. Information collection and validation rely on a range of further sources, including European and national regulations, official websites and annual reports, scientific literature, and last, but not least, a great array of interviews with Cohesion Policy experts.

Our method has been broken down into two steps. First, after the definition of irregularities we analysed the Hungarian regulatory, administrative and delivery regime of the EU funds in the period 2004-2018. Special attention was given to the issues linked to preventing and managing irregularities. In particular, changes in the government structure and adequate administrative capacity are looked at, followed by an analysis of their impact on Hungary's effective use of EU funds (Nyikos 2013). Secondly, we examined the evolution of the relevant legal framework linked to EU funds and irregularities. We assessed the data on irregularities in order to measure Hungary's performance and identify improvement needs, especially in light of the new "rule of law" initiative proposed by the European Commission. Whereas the present study principally attempts to systemise the Hungarian experience, the relationship between compliance enforcement and the efficacy of EU-funded public policy interventions has received growing attention in both EU institutions and Member State, and it is placed high on the agenda of the 2021-2027 legislative proposal negotiations. Furthermore, the discourse is not confined to Europe; uncertainties regarding the legal basis of federal grant assistance (Walker 1997) or (non-compliance related) dispute settlement structures and procedures (Marque 2011) constitute a reoccurring issue in the United States, as well.

10 Financial instruments are defined in Financial Regulation as measures of "financial support provided from the budget in order to address one or more specific policy objectives by way of loans, guarantees, equity or quasi-equity investments or participations, or other risk-bearing instruments, possibly combined with grants". 


\section{The evolution of the regulatory framework in Hungary}

This chapter offers a brief overview of the evolution of both the general legal-institutional framework Hungary has adopted for implementing the EU Cohesion Policy and the irregularity system it has built up to deal with the irregular use of the funds. It explains the main considerations for the continued recalibration of this delivery environment, the steps the Hungarian Authorities had to take to resolve systemic problems, the result of these interventions, and it also presents noncompliance handling issues yet to be resolved.

In the draft legislation for the 2021-2027 budgetary period, the European Commission proposes a new requirement, namely the rule of law conditionality. ${ }^{11}$ Its clarity and objectivity, however, are still being widely discussed. Additionally, cohesion policy conditionalities have always contained an obligation for the proper functioning of the institutions - including the courts. Nonetheless, the European Commission has not previously examined the performance of the courts in relation to proceeding irregularity and recovery disputes although Member States have met difficulties when they attempted to embed the irregularity and recovery managment functions in their national legislation.

This chapter summarises the evolution of national regulatory environment for irregularities. Domestic rules play a pre-decisive role in dictating the general legal relationship for the provision of financial assistance including the handling of irregularities and recoveries, assigning the corresponding rights and obligations to the financiers (represented by the managing authorities) and beneficiaries. Meanwhile the quality of the regulations (clarity, consistency, completeness) influences the solidity of decisions and enforcement of sanctions. The national legal basis has developed over the years; notably periodic re-examinations have been undertaken to incorporate the knowledge enriched by experience and to respond to the emerging problems the chapter will present. Nonetheless, the interplay of this public-lawbased legislative framework with civil law ruling the conclusion and satisfaction of grant contracts has generated growing difficulties for appeals.

\subsection{General approach to managing the funds and irregularities}

The Pre-Accession Funds paved the way for implementing Cohesion Policy via institutional capacity-building and modelling the implementation of the funds. The ex-ante controlled pre-accession system offered little opportunity to pilot the handling of irregularities under the shared management regime though. The National Development Plan of Hungary briefly mentions the term; the 2004-2006 domestic regulations did not offer much detail either; minimum standards were only adopted in 2005. Perceived security came from excessive administrative rules, high collateral requirements, and long delays in public procurement processes, which postponed

11 COM (2018)324 final, Rule of law conditionality proposal. 
the recognition of varied interpretations. ${ }^{12}$ Furthermore, the delivery system had limited exposure to external audits. These factors added up to a low level of risk recognition. Challenges were addressed case by case, as they arose, without the employment of systematic legal solutions.

Managing Authorities (MA) bore the general responsibility for implementing the operational programme and, as part of it, managing the irregularity system. They had to secure funding for the repayment to the EU budget (from the national budget reserves) before recovery from the beneficiary was accomplished. ${ }^{13}$ Managing Authorities delegated many of their functions to the 22 intermediate bodies (IB) which essentially satisfied the project-level tasks including dealing with irregularities, too.

The winding-up body (an independent control body to audit the delivery system and projects), being the Government Control Office in Hungary, was limited to informing the managing authorities on suspected irregularities $(5-15 \%$ control checks); only later was it empowered to state irregularities. The Paying Authority (PA), in charge of certifying expenditure and submitting applications for payment to the Commmission, followed up financial control and audit processes and coordinated with the MAs and IBs. The OLAF Coordination Office collected information and reported on irregularities, meanwhile offering guidance and training to help recognise potential fraud. The police, the prosecution, the courts and the Public Procurement Arbitration Board played an important role in the investigation, judgment and treatment of irregularities that fell under criminal law or the public procurement law.

When preparing for the period 2007-2013, a strong emphasis was placed on institutional and operational efficiency. The newly created National Development Agency hosted all managing authorities, and the new national regulations laid down unified standards for programme delivery. Irregularities received little importance initially. By the early 2010s their number rose alarmingly; intensifying EC audits strongly criticised Hungary's failures to check and ensure that beneficiaries comply fully with the public procurement rules (Nyikos and Tátrai 2012). Subsequent financial corrections called for high-level intervention, managing irregularities ceased to be treated as a technical matter. The new Government (2010) initiated a full-scale revision.

The organisation of political coordination ${ }^{14}$ was redefined. Managing authorities received reinforced responsibilities for directing and controlling a reduced number of IBs. A single set of implementing rules replaced the fragmented, ev-

12 Primary source of irregularities up to date.

13 As the CSF Managing Authority was in charge of the use of technical assistance monies related to the implementation of the CSF, its duties included corresponding recovery. A similar obligation was ascribed to the Cohesion Fund IB.

14 Assigned to the Minister responsible for national development. 
er-sprawling regulations. The provisions on irregularities were upgraded significantly, the introduction of the right to appeal bettered the substantiation of decisions. Besides, appalling differences in the recovery rate called for action. Principally the operational programmes ${ }^{15}$ which focused on public-sector target groups, where the techniques of direct reduction from the payment claim or direct collection ${ }^{16}$ were in place, progressed with the repayments satisfactorily. They achieved a close to $100 \%$ recovery rate. Other programmes presented outstanding delays. Eventually the National Tax and Customs Administration was appointed to recover the funds as overdue tax reinforced by its right to "delete a company's registration number", this measure instantly terminates the trading of the firm.

For the 2014-2020 period a complete transformation of the delivery system implied that managing authorities and most intermediate bodies were reinstiuted into the line ministries. ${ }^{17}$ Sectoral policy responsibilities received crisp articulation in the new national regulations. The Minister in charge of the EU Funds was appointed to supervise implementation, supported by a Central Coordination Unit holding significant powers. The Government decree ${ }^{18}$ passed in autumn 2014 comprises standardised implementing provisions, national eligibility rules and a unified operational manual. Cutting red tape in collateral requirements necessitated that the means to recover the misused public funds are solidified.

Detailed rules apply to the investigation and treatment of irregularities. The process always starts with an alert by an institution or official in the management and control system; the signal is then followed up by the managing authority. The irregularity examination process may require coordination with external agencies or authorities and/or spur the discontinuation of the payment of financial assistance. The decision whether compliance or rather the violation of the norms and financial loss were evidenced rests with the head of the MA. The beneficiary may request a re-examination; during the appeal process, save the halting of payments, the legal consequences are suspended. Depending on the nature of the case, the managing authority may waive the beneficiary's repayment obligation; in case of a negative appeal judgment, however, interest is charged on the unpaid "debt".

\subsection{Regulations for implementing the funds and handling irregularities}

Irregularity provisions have always formed part of the broader Cohesion Policy regulation. For the period 2004-2006 multiple layers of regulations included government and ministerial decrees, OP-specific rules and operational manuals issued

15 E.g. Electronic Administration, Public Administration Reform, Technical Assistance, Transport.

16 Direct charge of the beneficiary's bank account.

17 Some of the MAs (Public Administration, Rural Development) are hosted by the PMO.

18 Government Decree 272/2014. (XI. 5.) on the implementation of assistance from EU Funds in the programming period 2014-2020. 
by MAs and IBs. The involvement of multiple agencies with overlapping duties and continued modification of the regulations created difficulties in maintaining a nationally consistent approach and precipitated the capacity of project promoters leading to higher compliance risks. Irregularity and recovery provisions were incomplete $^{19}$, supplementary rulings were only passed in March 2005. For the Europan Rural Development Funds, the authorisation of a government decree ${ }^{20}$, public administrative procedures formed the legal grounds for the receipt of $\mathrm{EU}$ funds.

For the period 2007-2013 the nature of the regulatory framework remained unchanged: fragmented rules and an institution system with more than 25 executing bodies and overlapping regulations led to tangible departures in legal interpretation.

The complete mid-term revision encompassed the irregularity system. ${ }^{21} \mathrm{Ob}$ servations included weaknesses of the multilevel regulatory environment; despite the legislative hierarchy neither legal dogmatics nor application of the rules evidenced the regulatory intent of coherence and legal consistency. Particular insufficiencies contained the lack of

- clarity on institutional duties and their embeddedness in the national public and civil law systems,

- certainty on public authority power, legal nature of grant assistance limiting the right to appeal,

- defined authority of the courts in case public financial assistance cases are tried,

- procedures for coordinating with bodies ${ }^{22}$ whose decisions impact ${ }^{23}$ on the regularity of the funds.

The rules required a full-scale process for all irregularities, even if the national regulations offered sufficient clarity for closing down the case $^{24}$ (e.g. liquidation,

19 The Government first adopted implementing rules for Cohesion Policy funds in January 2004. This first piece of legislation laid down the institutional responsibilities for managing Structural and Cohesion funds in Hungary. The list of definitions shows an explanatory nature rather than purely quoting the EU legislation. Nonetheless, the definition of irregularities was excluded.

20 82/2007. (IV. 25.) Government Decree.

21 A comprehensive review of the regularity framework for handling irregularities under Structural Funds, prepared by the EX ANTE-MEGAKOM-ECORYS Konzorcium for the Coordination Managing Authority of the National Development Agency, July 2010.

22 The Public Procurement Arbitration Board formed an exception; the volume of non-compliance cases in the public-procurement domain had inspired the improvement and formalisation of working relations at an earlier stage.

23 E.g. Competition Office, tax authorities, criminal courts.

24 Another important observation focused on the relationship between the management verification and the irregularity systems. Empirical evidence, which was obtained for the preparation of the study, suggested that the irregularity system actually replaced underperforming first-level control functions. This practice was strongly recommended to be brought to a halt in order to give way to the parallel upgrading of these two inter-related regimes. 
bankruptcy). At the closure of the 2004-2006 programmes, the buildup of a serious backlog came to the forefront.

The need to introduce substantial changes became inevitable. In 2010 a unified government decree ${ }^{25}$ was introduced, offering a clear distribution of tasks between MAs and IBs, detailed provisions on public-procurement compliance checks, complaints and irregularities. Beneficiaries could challenge decisions at any stage of the administrative process.

For the period 2014-2020 the Government radically recalibrated the programming architecture, the legislative and institutional environment and enacted a new government decree ${ }^{26}$ in autumn 2014.

\subsection{Legal relationship with the beneficiary, the problem of the legal regime}

The importance of the legal relationship between the beneficiary and the managing authority lies in the guarantees it offers for the enforcement of - financial sanctions, should an irregularity be established, whereas it also gives the right to beneficiaries to challenge such a decision. Its terms and conditions derive from the governing legal regime, the effectiveness of which has a significant influence on how these rights and obligations are fulfilled. Problems, however, quickly become reoccurring, and legal difficulties multiply with the interplay of various legal regimes.

Legal issues related to the award, use and repayment of public financial assistance in Hungary are partly covered by administrative law and partly fall within the civil legal system with important overlappings.

Academic literature in Hungary has applied greater weight to the public source of law. Public-policy objectives spur public authorities to allocate financial assistance via their redistributive functions; the recovery of aid is based on public-finance law. The efficient and effective use of budget funding is in the public interest, even if it takes the form of a private investment. Therefore, public-finance law dominates the process, covering the award decision, release of assistance, reporting, recovery and financial control.

However, the absorption of EU Funds has been accompanied by a dynamically growing array of support forms. Contractual arrangements are based on civil law with several elements from public finance law. This complexity negatively affects the

25 4/2011. (I.28.) Government Decree on the use of assistance from ERDF, ESF and the Cohesion Fund in the programming period 2007-2013.

26 Government Decree 272/2014. (XI. 5.) on the implementation of assistance from EU Funds in the programming period 2014-2020. 
transparency of the legal structure of the relationship between the parties (financier and beneficiar $y^{27}$ ) and the application of the rules.

The legal relationship between the managing authority and the beneficiary starts with entering into a legally binding agreement which may take the forms of $i$.) a grant contract, ii.) a grant letter and iii.) a public administrative decision.

In the period 2007-2013 the EARDF grant provider MA in Hungary acted as a public authority under administrative law, adopting public administrative decisions, while the ERDF, ESF and Cohesion Funds MAs acted under civil law and issued grant contracts and grant letters.

For the ERDF, ESF and Cohesion Fund the contract which the two parties signed was governed by the Civil Code, from the day of its conclusion up to its termination. These terms were clearly expressed in the 2007-2013 implementing provisions, doubtless as a reaction to the uncertainty the legal status of the grant contract had caused earlier. To simplify, managing authorities introduced and issued grant letters as a one-sided act. A grant letter sets forth all the conditions attached to implementing the funds, which the beneficiary formally accepts through the submission of the grant application. Grant letters are regimented by civil, in particular contract, law, too.

Different provisions applied to EARDF assistance in the period 2007-2013. The general rule dictated that the award of financial support is based on a formal public administrative decision. Public administrative decisions must be public-authority-related, namely determining rights or obligations for addressees, verifying data, facts or eligibility, maintaining official records and carrying out controls. The managing authority satisfied all these functions; moreover, a decision on an application for financial assistance implies the determination of rights and duties. Consequently, the formal criteria for a public administrative proceeding were fully met.

The broader legal environment, the appropriate regulatory framework, gains utmost importance if a beneficiary fails to fulfil the contractual obligations or the misuse of funds is evidenced, triggering the recovery of public moneys. The legal status of the irregularity decision directly influences the right of the beneficiary to challenge this decision as well as being a vital component for the efficiency of the corrective measures the managing authority puts in place.

In the EARDF regime when projects are approved via an administrative proceeding the law records the need to conclude an irregularity decision in the form of an administrative proceeding. Two procedures can be distinguished: i.) administrative decision with immediate effect ${ }^{28}$, whereby no right of appeal is provided, enti-

27 Beneficiaries portray a great variety of organisations like private companies, NGOs, civil organisations and churches, public utility companies, ministries and government agencies, the territorial administration and local governments.

28 Law XVII of 2007 Article 69 (7)-(8). 
tlement of the beneficiary for financial support terminates, entirely or partially, and ii.) withdrawal of the previous decision on the award of financial assistance associated with the right to appeal; the outcome of the second-tier decision shall prevail.

Civil courts have inherent jurisdiction to try irregularity-related sanctions imposed on beneficiaries. However, there was no uniform understanding of the authority civil courts held in such cases and the position only started to be confirmed by actual court practice in the early $2010 \mathrm{~s}^{29}$

Ambiguity in the legal provisions led to multiple interpretations regarding the position of the managing authority when it commences proceedings to formally establish the irregularity and deal with its consequences. Managing authorities argued that their co-ordinated, equal legal standing with the benefiary within the grant contract does not convert into an identical relationship within irregularity disputes. Their duty to seek and guard the interest of the EU and national budgets, the obligations stemming from the EU legislation and imposed on them as functions to be satisfied by the national authorities, play out as essential drivers to their conduct. With the signature of the grant contract, the beneficiary acknowledges and accepts the right of the managing authority to exercise power, including the establishment of irregularities and the enforcement of legal and financial consequences accordingly. Also jurisdictions contained opinions which noted that beneficiaries obtained public funds through a call-for-proposals system, whereby all implementing conditions derived from regulations. The autonomy of the beneficiaries was thus limited to accepting or rejecting the contractual terms (and the funding offer).

Consequently, the relevant current Hungarian regulations state for every type of national public and EU funded assistance that the selection and the recovery/repay process is based on the public-finance law with a civil contract concluded between the parties.

The update of the delivery terms for the EU funds extended to the challenge of the irregularity decision. A second tier to the irregularity system was introduced to address the request of beneficiaries for an administrative review of the first-level decision. As the appeal decision does not constitute a public administrative proceeding, the implementing decree does not entitle the beneficiary to file an appeal against this second-tier decision (on the irregularity itself or the recovery of undue assistance) to the court. Nonetheless, on the consideration of the legal relation between the managing authority and the beneficiary being governed by civil law, beneficiaries can file a civil lawsuit against the second-tier position. In this case, they

29 Most relevant decisions: 1/2012 (XII.10.) KMK.-PK. Opinion EBH2010.2237, 2237/2010. Economic Precedented Opinion, Supreme Court Gfv.IX.30.218/2011/7. Judgment. 
do not compel the decision itself but allege the cancellation of the grant contract ${ }^{30}$ requesting the continuation of funding to the project. ${ }^{31}$

These provisions are not in line with the rule of law and seem to be unconstitutional as Hungary's Fundamental Law (Article XXVIII) rules that "(1) Everyone shall have the right to have any charge against him or her, or his or her rights and obligations in any litigation, adjudicated within a reasonable time in a fair and public trial by an independent and impartial court established by an Act" and "(7) Everyone shall have the right to seek legal remedy against any court, authority or other administrative decision which violates his or her rights or legitimate interests." Additionally, Article 25 (2) specifies that "Courts shall decide on a) criminal matters, civil disputes and on other matters specified in an Act."

The rule-of-law principle dictates that beneficiaries obtain the right to challenge the irregularity decision of the managing authority. Also the efficiency of the appeal regime determines the time required for settling a dispute and recovering undue assistance. Court proceedings take many years, conserving uncertainty and feared to decrease the probability of an effective recovery. A performance audit by the National Audit Office ${ }^{32}$ of 2010 noted that settling an appeal took an average of 3 years.

Additionally, the status of Commission guidelines is yet unresolved, the national rules do not offer techniques for their treatment. As an example, the guidelines to be applied for irregularities related to public procurement define the amounts and rates of financial corrections (Nyikos and Sóos 2016). Although the guidelines do not constitute legislation, both the Commission services and Member State authorities have to adhere to them. Other concerns include their retroactive employment and legally expansive nature: the guidance must be based on EU law to provide clarification for the practicacl implementation of the ruled. However, these guidances repeatedly go beyond the regulation.

30 E.g. Supreme Court Gfv.IX.30.218/2011/7 (First tier: Economic Collegium of Budapest Court 22.G.41.644/2007/38; Second tier: 4.Pf.31.997/2010/3); Budapest Regional Court of Appeal 3.Pf.20.373/2013/4. Judgment (First tier: Economic Collegium of Budapest Court 25.G.40.350/2011/8);

- Budapest Regional Court of Appeal 17.Pf.20.050/2015/6. Judgment (First tier Economic Collegium Budapest Regional Court 19.G.40.366/2014/14);

- Budapest Regional Court of Appeal 9.Pf.20.015/2012/7. Judgment (First tier: Budapest Regional Court 66.P.23.359/2011/9).

31 E.g. Budapest Regional Court of Appeal 16.Gf.40.152/2014/13. számú second tier judgment (First tier: Economic Collegium Budapest Regional Court 7.G.40.001/2013/6);

- Supreme Court Gfv.IX.30.334/2011/5. és Gfv.VII.30.179/2014/4. Judgments (First tier: Economic Collegium of Budapest Court 19.G.40.704/2010/6, second tier: Budapest Regional Court of Appeal 9.Pf.20.303/2011/3 and 9. Pf.21.524/2012/3).

321010 Report on the audit of the irregularity, debt and recovery processes related to the use of EU Funds (2010) National Audit Office. 


\subsection{Hungarian irregularity data and trends}

Statistical data as of 31 January 2018 confirm that documents-based checks constitute the principal instrument to reveal irregularities (59\% of all cases). Timely investigation is essential to the pace of the recovery process. When an investigation confirms full compliance in a project, the "return to normalcy" should take place instantly. Cases are very different, of course. Certain types of issues take almost no time to process; highly complex, specialised problems require a longer examination. The maximum length of investigation dropped markedly over the years, concluding an irregularity takes less than a day in $20 \%$ of the cases. Nevertheless, the average examination time remained unchanged.

Table 1

Timescale of irregularity examinations

\begin{tabular}{|l|c|c|}
\hline & 31 December 2009 & 31 January 2018 \\
\hline Maximum (no. of days) & 509 & 382 \\
\hline Minimum (no. of days) & 4 & 0 \\
\hline Average (no of days) & 65 & 66 \\
\hline Regulatory deadline (no. of days) & 45 & 45 \\
\hline Investigated within 45 days (\%) & $42 \%$ & $36^{33} \%$ \\
\hline
\end{tabular}

Source: Data from National Audit Office Report, Prime Minister's Office.

The volume of reported irregularities stood at a relatively low level in the period 2004-2008; however, it rocketed in 2009. The number of cases grew fivefold, and the rate of assistance impacted by irregularities soared eightfold. A steady rise of irregularities followed, and by the end of the programming period a strong concentration became apparent in the economic development and regional operational programmes. Recovery rates ranged from $8 \%^{34}$ to $157 \%$ across the entire programming architecture. ${ }^{35}$

At present, comparisons are hard to make, as mass-scale project implementation started only in 2016 and the first irregularity was noted on 10 May 2016.

33 However, the value for the rate of investigations accomplished within 50 days is $54 \%$.

34 Economic Development OP.

35 Outstanding recoveries were subject to penalty interest rates. 
Table 2

Breakdown of irregularities in the period 2014-2020

\begin{tabular}{|l|c|}
\hline \multicolumn{1}{|c|}{ Operational Programme } & Percentage of irregularities \\
\hline Economic Competitiveness and Innovation OP & 66 \\
\hline Human Resource Development & 4 \\
\hline Transport (all public procurement) & 7 \\
\hline Environment (all public procurement) & 7 \\
\hline Public Administration & 3 \\
\hline Territorial and Settlement Development & 9 \\
\hline Competitive Central Hungary & 4 \\
\hline Total & $\mathbf{1 0 0}$ \\
\hline
\end{tabular}

Source: Based on data from the Prime Minister’s Office, 31 January 2018

As the above table illustrates, the spread of irregularities across the operational programmes is rather uneven, the Economic Competitiveness and Innovation OP holds a dominant share of irregularity cases. This is partly due to the quick start of this programme inducing the launch of a large number of projects as well as the particular difficulties (bankruptcy, liquidation, ownership transformation etc.) private sector beneficiaries struggle with.

\subsection{Sources of irregularities}

Sources of irregularities have long fallen into a limited number of categories. Most of the irregularities are linked to public procurement (29\%) and ineligible expenditure $(30 \%)$. The present over-representation of the Economic Competitiveness and Innovation OP came with the rising challenges (e.g. liquidation, bankruptcy and other processes) beneficiary firms have to struggle with. Breach of public procurement rules account for a very high proportion of repayments. Operational programmes with public-sector beneficiaries and large-scale procurements are particularly "vulnerable" to non-compliance. Since the mid-2000s, the nature of non-conformity has moved from the employment of inadequate procedures to restricting competition and sound financial management, its lack of definition re-occurs with each public procurement audit. Neither pure reference to this principle nor the observation of reduced competition helps to understand how the fundamental concept should translate into practice. Auditors' observations on restrictions to equal and fair competion display great procedural variations in terms of the size of evidenced market interest, the signs of any perceived inhibit to entry (e.g. ex-ante settlement request, appeals) or the ratio of the planned vs. actual tender value (Tátrai and Nyikos 2012). Growing concerns are reflected in the $\operatorname{paper}^{36}$ compiled by the Legal Interpretation

36 Supreme Court 2015.El.II.JGY.E.1.1. Jurisdiction Practice in Public Procument, Summary Report by the ad-hoc Legal Interpretation Analysing Group of the Supreme Court. 
Analysing Group of the Supreme Court, noting that the principle of sound financial management, ingrained in Hungary's Public Procurement Law, is difficult to interpret. It is not applicable as a general clause, it is of economic rather than legal content, and it does not trigger a legal impact. Appraising the soundess of management practices is subjective, which cannot be scientifically or empirically measured, its boundaries cannot be defined. Therefore, attaching legal consequences to this criterion is perceived as a rather ambitious attempt. ${ }^{37}$

Market prices have recently received critical audit observations. For purchases via public procurement, the outcome of the competition is generally accepted as the market price. For items/services with a value below the public procurement threshold, a different approach has been taken. The Hungarian rules on eligibility dictate that any expenditure which the beneficiaries submit must follow the market prices. A failure to offer hard evidence on the adequacy of the prices provokes the rejection of the expense as ineligible. A range of instruments has recently been put in to help beneficiaries, simplify the assessment of the price range and reduce audit risks. These include the use of three independent quotes, the employment of capped budget categories, unit prices or reference to official rates. Ensuring an acceptable price range needs robust checks and proper documentation of the probings. At present, a $20 \%$ departure from the perceived market price is allowed.

The risk of irregularities remained high as the root problems are manifold. Grant culture inspires beneficiaries to maximise funding opportunities. Market prices constantly change and reflect the information on the availability of sizeable public funds. Labour market changes, lack of skilled workers and demand propelled by the cyclical nature of programmes have led to rising costs. Comparisons with previous public tenders are becoming irrelevant.

These complications are evidently not unique to Hungary. It is tempting to address the symptoms, and financial corrections imposed on the Member States indeed do so, nonetheless only finding and reacting to the root of the problems could radically improve the regularity of the funds.

\section{The "new" approach: Rule of law}

After analysing the evolution and the particular Hungarian context and understanding the importance of the proper and legal functioning of the implementation system, this chapter takes stock of the main considerations for the future of the irregularity system with a view to the new rule of law conditionality under the 2020+ Cohesion Policy.

37 The report also suggests that other pieces of legislation contain very specific norms for the use of public funds. 
The use of conditionalities in Cohesion Policy has been significantly extended (Nyikos 2014) to date, containing macroeconomic conditionality, ex-ante conditionalities (and are proposed to be further widened in the next period with the infringement conditionality). The exisiting conditionalities and legislative provisions dictate the obligations which the implementing entities of the Member States, including the organs in charge of managing irregularities, have to satisfy, and should these duties be in need of enforcement, the Commission is equipped with effective instruments to terminate or suspend payments. For the regular implementation of Cohesion Policy, the proper functioning of the relevant institutional system has always served as a pre-requisite. Due to irregularities, in a broader sense the judiciary has also formed part of the implementation system (Nyikos 2019). Nonetheless, the European Commission has not previously examined the functioning of the courts in relation to the irregularity and recovery cases, although embedding these functions into the national legislation has gone beyond being a solely Hungarian problem (Talaga and Nyikos 2014).

The 2021-2027 legislative proposals present a new rule of law conditionality ${ }^{38}$ as a stand-alone, cross-cutting requirement applicable to all EU budget expenditure, including Cohesion Policy. The provisions comprise conditions specific to Cohesion Policy as well as EU legal principles, constitutional rights and requirements deriving from the concept of the rule of law. As mentioned earlier, there has been no attempt by the European Commmission so far to subject the exercising of the judicial functions in Cohesion Policy related cases to scrutiny. The proposal provoked both political and legal debates, principal concerns relate to the transparency, clarity and objectivity of the rule of law provisions.

Beneficiaries enjoy the constitutional right to file a claim in an independent and impartial court. The absence of this protection would violate their constitutional rights and may also raise fears among them about the political influence which at the second level of the administrative disputes' resolution may occur. The scrutiny of the legality of the sanctions by the independent judiciary bears essential importance, as recorded in the European Convention of Human Rights, the Charter of Fundamental Rights of the European Union and the Treaties and reflected by Court practice. ${ }^{39}$ The existing instruments, the actual Commission and Court practices raise dilemmas about what value added the new provisions will offer. Furthermore, the present wording of the legislative proposal does not offer sufficient clarity on the nature, gravity and scope of the generalised deficiency which may trigger the Commission's intervention; regulatory conditions, instead of promoting the noble goal of safeguarding the rule of law, may become a powerful political instrument.

38 COM (2018)324 final, Rule of law conditionality proposal.

39 Court Decision C-619/18 R (19 October 2018). 
Appropriately, the opinion of the European Court of Auditors confirms the need for substantiating a judgment of deficiency with specific criteria. ${ }^{40}$

\section{Discussion}

This chapter provides for a short summary of the significant points made earlier in relation to the key milestones the evolution of the irregularity system in Hungary has shown so far and the outstanding issues yet to be resolved.

Since its first programming period, Hungary has notably stabilised its irregularity structures and mechanisms, including the continued development of the regulatory and administrative framework. This progress has been largely inspired by the growing exposure to administrative and financial sanctions. Accordingly continued efforts contributed to improved institutional capacity and the introduction of specific instruments and techniques to deal with high-risk areas, whereas the launch of an appeal system advanced the protection of beneficiaries. However, the process is far from complete. The long-known need to resolve the nature of the legal relationship between grantee and the grant provider has become inevitable. The Hungarian appeal system needs to be re-examined, since available administrative dispute procedures do not replace the full-scale judicial oversight, a last-resort protection in the Constitution.

The EU legislation has dictated the ingrained authority of the European Commission to discontinue the transfer of Cohesion Policy funds, should systemic shortcoming be recognised in a Member State. Discussions on the irregularity and appeal systems have been ongoing between the Commission and the Hungarian Authorities, yet the approach to accessible dispute resolution and justice has presented ambiguity and inconsistencies over time.

This leads to the rule-of-law principle, the employment of which requires utmost precision in terms of the clarity of specific requirements Member States are obliged to fulfil when using Cohesion Policy funds. In addition, the in-depth analysis and addressing of the root problems, which repeatedly invoke irregularities, yet awaits. The current financial implementation and control regime (annuality) has not rectified the long-lasting difficulties. Non-conformity has not ceased to trouble managing authorities. Out of fear to induce systemic irregularities if non-compliance of spending is revealed after the annual accounts are submitted, they reduce their risks by excluding the feared items. Treating a symptom is very far from fixing the problem. Without the latter, national budget will bear the burden; legal uncertainty will not be removed either.

40 Court of Auditors Opinion No 1/2018 (pursuant to Article 322(1)(a) TFEU) concerning the proposal of 2 May 2018 for a regulation of the European Parliament and of the Council on the protection of the Union's budget in case of generalised deficiencies as regards the rule of law in the Member States (2018/C 291/01). 
Last but not least simplification and compliance strongly correlate. New methodologies are required to provoke the regulatory concept at both EU and national levels, identify redundancies and push forward towards a really radical cutback of red tape.

\section{References}

AAM Consulting. 2012. The Evaluation of Regulatory Contraints. National Development Agency/Prime Minister's Office. Available at https://www.palyazat.gov. hu/szabalyozasi_kotottsegek_ertekelese.

Koedijk, M. (2016). EU cohesion policy and accountability coverage, context, content and costs in the case of ERDF in the Netherlands. Enschede: Universiteit Twente. https://doi.org/10.3990/1.9789036540261

Davies, S. 2015. Is Simplification Simply a Fiction? IQ-Net Thematic Paper 37(2); European Policies Research Centre School of Government \& Public Policy University of Strathclyde.

Davies, S and L. Polverari. 2011. "Financial Accountability and European Union Cohesion Policy.” Regional Studies 45(5):695-706 DOI:10.1080/00343404.2 010.529118

Dragan, G. 2008. "Who's Afraid of the Absorption Capacity? A Romanian Perspective." Presented at 48 ${ }^{\text {th }}$ ERSA Congress, 27-31 August 2008, Liverpool, United Kingdom.

Grazianoa, P. and C. Halpern. 2015. EU Governance in Times of Crisis: Inclusiveness and Effectiveness beyond the 'Hard' and 'Soft' law divide. Comparative European Politics DOI:10.1057/cep.2015.6

Hajdu, Sz., Zs. Kondor, K. Kondrik, M. Miklós-Molnár, G. Nyikos, G. Sódar 2017. "Kohéziós Politika 2014-2020" Budapest, Magyarország: Dialóg Campus Kiadó, 614 p.

Hoffman I. 2018 “Bevezetés a területfejlesztési jogba”. Negyedik kiadás, Budapest ELTE EöTvös kiadó, 150p.

Horvat, A. 2005. "Why does Nobody Care About the Absorption?" WIFO WorkingPaper 258/2005.

Horvat, A. and G. Maier. 2004: Regional Development, Absorption Problems and the EU Structural Funds: Some Aspects Regarding Administrative Absorption Capacity in the Czech Republic, Estonia, Hungary, Slovakia and Slovenia, $44^{\text {th }}$ Congress of the European Regional Science Association: "Regions and Fiscal Federalism", $25^{\text {th }}-29^{\text {th }}$ August 2004, Porto, Portugal, European Regional Science Association (ERSA), Louvain-la-Neu. 
Idczak, P. and I. Musiałkowska. 2014. "Assessment of the System of Project Selection under the Cohesion Policy: The Case of the Wielkopolska Region." Evaluační teorie a praxe Ročník 2(2), 1-31.

Jouen, I. 2008. Territorial Cohesion: From Theory to Practice Notre Europe. (๑ Notre Europe, June 2008 1-31.

Jurevičienè, I. and I. Pileckaitè. 2013. "The Impact of EU Structural Fund Support and Problems of its Absorption." Business, Management and Education 11(1), $1-18$.

Kalman, J. 2002. "Possible Structural Funds Absorption Problems: The Political Economy View with Application to the Hungarian Regional Development Institutions and Financial System." Budapest: Central European University.

Kopeva, D., R. Laplana, B. Huatdidier, N. Turpine, L. Jelinek, M. Raley, M. Njavro and O. Baquiero. 2011. "The Role of Multilevel Governance for Multifunctional Land Use Activities." IASC European meeting, 14-17 September 2011, Agricultural University, Plovdiv, Bulgaria.

Łacny, J. 2017. "Between the Devil and the Deep Blue Sea: The CJEU Case-Law on Financial Corrections Imposed by the Commission on the Member States." Journal of Contemporary European Research 13(2), 1043-1054.

Marque, A. 2011. "A New Appeals Board: Providing Consistency and Clarity in the World of Grants and Cooperative Agreements." Public Contract Law Journal 41(1), 129-148.

Mendez, C. and J. Bachtler. 2017. "Financial Compliance in the European Union: A Cross-National Assessment of Financial Correction Patterns and Causes in Cohesion Policy." Journal of Common Market Studies 55(3), 569-592.

Meuleman, L. and A. Brenninkmeije. 2017. "How to Deal with Legal Uncertainty: Managing and Audit Authorities in Cohesion Policy." European Structural and Investment Funds Journal Volume 5 (2017), Issue 2, 161-173.

Mike, K. and G. Balás. 2015. "Measuring for Absorption: How the Institutionalisation of EU Cohesion Policy Influences the Use of Performance Indicators in Hungary." NISPAcee Journal of Public Administration and Policy 8(2), 125-147 DOI: https://doi.org/10.1515/nispa-2015-0012.

Nyikos, G. 2012. "Végrehajtási intézményrendszer a kohéziós politikában." Polgári szemle: Gazdasági és társadalmi folyóirat 8(3-6), 140-164.

Nyikos, G. 2013. "A közfinanszírozásból megvalósított fejlesztések hatásai, különös tekintettel az EU kohéziós politikára." Pénzügyi szemle/Public Finance Quarterly 2, 165-185. 
Nyikos, G. 2014. "Development Policy in an Age of Austerity: Result-orientation, Effectiveness and Sustainability". In I. Pálné Kovács and C. M. Profiroiu (eds). Regionalisation and Regional Policy in Central and Eastern Europe: Selected Revised Papers from the $21^{\text {st }}$ NISPAcee Annual Conference, May 16-18, 2013 Belgrade, Serbia. Bratislava: NISPAcee, 165-188.

Nyikos Gy 2011. “Területi tervezés és területi szempontok a fejlesztéspolitikában” FALU VÁROS RÉGIÓ 18: 2 pp.35-41, 7 p.

Nyikos, G. and Sz. Szabó 2019. "Irregularities in the EU Cohesion Policy - Hungarian Experiences and Lessons Learned." European Mirror 2019 Budapest 67-85.

Nyikos, G. and G. Soós. 2016. "Kohéziós politika és közbeszerzés együttes alkalmazásának lehetőségei és kihívásai az új szabályozás fényében.” Közbeszerzési szemle 5, 45-60.

Nyikos, G. and G. Soós. 2018. "Financial Instruments in EU Cohesion Policy and Public Procurement: Challenges for the 2014-2020 Programming Period." Public Procurement Law Review 32, 120-137.

Nyikos, G. and G. Soós. 2019. “The Hungarian Experience of Using Cohesion Policy Funds and Prospects." In Idczak, P. and I. Musiałkowska (ed.). EU Cohesion Policy in Eastern and Southern Europe: Taking Stock and Drawing Lessons for the Future. De Gruyter.

Nyikos, G. and T. Tátrai. 2012. "Public Procurement and Cohesion Policy." CP33 Competitive paper.

Parker, C. 2000. Reducing the Risk of Policy Failure: Challenges for Regulatory Compliance. Paris: OECD.

Šumpíková, M., J. Pavel, S. Klazar and O. Potluka. 2005. "European Union Funds: Absorption Capacity and Effectiveness of their Use, with Focus on the Regional Level in the Czech Republic." In G. Jenei, A. Barabashev and F. van den Berg (eds). Instititutional Requirements and Problem Solving in the Public Administrations of the Enlarged European Union and Its Neighbours: Selected Papers from the $12^{\text {th }}$ NISPAcee Annual Conference Vilnius, 2004. Bratislava: NISPAcee.

Suwaj, P. J. 2005. "Preventing Corruption and Conflict of Interest: Necessity or Fashion? The Case of Poland." In G. Jenei, A. Barabashev and F. van den Berg (eds). Instititutional Requirements and Problem Solving in the Public Administrations of the Enlarged European Union and Its Neighbours: Selected Papers from the $12^{\text {th }}$ NISPAcee Annual Conference Vilnius, 2004. Bratislava: NISPAcee. 
Talaga, R. and G. Nyikos. 2014. "Cohesion Policy in Transition: Comparative Aspects of the Polish and Hungarian Systems of Implementation." Comparative Law Review (TORUN) 18, 111-139.

Tátrai, T. and G. Nyikos. 2012. "The Uses and Abuses of Public Procurement in Hungary." In G. L. Albano, K. F. Snider and K. V. Thai. Charting a Course in Public Procurement: Innovation and Knowledge Sharing. Boca Raton: (FL), Amerikai Egyesült Államok: Pracademics Press, (2013) pp. 29-54, 26 p.

Triga, I., I. Vasiliki-Vadratsikas and I. Konstantinos. YEAR. "Framing of Cohesion Policy." Available at http://www.cohesify.eu/wp-content/uploads/2018/03/ Cohesify_ResearchPaper9_Framing1.pdf

Walker, J. C. 1997. "Enforcing Grants and Cooperative Agreements as Contracts Under the Tucker Act." Publich Contract Law Journal 26(4), 683-707. Availabe at http://www.jstor.org/stable/25754281

Wostner, P. 2007. “The Micro-efficiency of EU Cohesion Policy." European Policy Research Paper 64. 